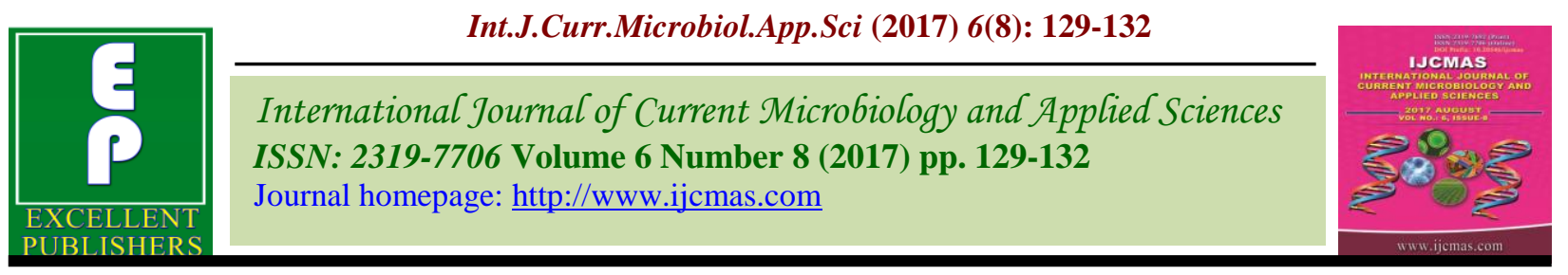

Original Research Article

https://doi.org/10.20546/ijcmas.2017.608.017

\title{
Screening of Mungbean (Vigna radiata (L.) Wilczek) \\ Varieties against Whitefly (Bemisia tabaci Genn.) and Mungbean Yellow Mosaic Virus (MYMV)
}

\author{
Nadeya Khaliq, Virender Koul, Uma Shankar, Suheel Ahmad Ganai", \\ Sonika Sharma and Thanlass Norboo
}

Division of Entomology, FoA, Main Campus, SKUAST-J, Chatha, Jammu -180 009, J\&K, India

*Corresponding author

\section{A B S T R A C T}

Keywords

Screening,

Mungbean,

whitefly, Mungbean

Yellow Mosaic

Virus.

Article Info

Accepted:

04 June 2017

Available Online:

10 August 2017
Field screening of 5 mungbean varieties for resistance against whitefly, induced Mungbean Yellow Mosaic Virus (MYMV) was carried out during Rabi and Kharif on 2014. Population of whitefly ranged from 3.22 to 7.69 per plant while MYMV incidence ranged from 6.00 to 39.00 per cent during Zaid 2014. Only one variety Pant Moong-1 was found to be resistant to whitefly during Zaid 2014. Pusa Baisakhi, PS-16 and Type-44 were susceptible and SML-668 was found to be moderately susceptible. During Kharif 2014, population of whitefly ranged from 40.67 to 82.62 per plant while MYMV incidence ranged from 15.22 to 79.00 per cent. Pant Moong-1 was found to be moderately resistant to whitefly. SML-668, PS-16 and Type-44 were susceptible and Pusa Baisakhi was found to be highly susceptible.

\section{Introduction}

Mungbean, [Vigna radiata (L.) Wilczek] is considered as one of the most economically important food legume crops of India. In India, it is the third most popular pulse crop after chickpea and pigeonpea. Despite its short duration, nearly 85 insect pests attack mungbean from field to storage. Aphids, whitefly, leafhopper, thrips, stem fly, pod bug and pod borer complex are more significant on mungbean throughout the country. Among these, whiteflies act as vector of mungbean yellow mosaic virus (MYMV) (Sekar and Nalini, 2017). Yellow mosaic virus causes irregular yellow and green patches on older leaves. Affected plants produce less number of pods and flowers and few seeds. It can cause yield losses of 30 to 70 per cent (Marimuthu et al., 1981). The cheapest, practical and economical control of the pest and disease can be achieved by the resistant source of insect and disease. Host plant resistance provides an alternative option to overcome insect pests under intensive cultivation system. Therefore, it is necessary to identify resistant/moderately resistant genotype to reduce the insect and disease population as well as the production cost to protect the environment. The present investigation on the identification of the sources of resistance is present-day requisite. In Jammu \& Kashmir, no such work has been done on this aspect. Therefore, keeping in 
view the economic importance of the crop the present study has been proposed.

\section{Materials and Methods}

Field screening was carried out at University Research Farm, Chatha, SKUAST-Jammu during Rabi and kharif of 2014 with 5 mungbean varieties viz., SML-668, PusaBaisakhi, PS-16, Pant Moong-1 and Type-44 under pesticide free condition. Each variety was sown in a plot size $(4 \times 3 \mathrm{~m}, 30 \times 10 \mathrm{~cm}$ RXR and PXP spacing). Each treatment was replicated two times in a Randomized Block Design (RBD). After germination, the crop was regularly monitored for the presence of whitefly and development of yellow mosaic disease per plant. Disease severity was recorded at weekly interval using 0-5 scale (Bashir, 2005) (Table 1).

\section{Results and Discussion}

In the field screening of five commonly grown mungbean varieties, the whitefly population ranged from 3.22-7.69 per plant during Zaid 2014 as given in (Table 2). Among the five varieties screened against whitefly, only one variety "Pant moong-1" was found resistant with a score of 1-10. The variety SML-668 was found moderately susceptible against whitefly with a score of 21-30. The varieties Pusa Baisakhi, PS-16 and Type-44 were found susceptible with a score of 30-50. Out of the five varieties screened against whitefly, none of the varieties were found highly resistant or highly susceptible. The MYMV incidence ranged from 6.00 to
39.00 per cent. Significantly low incidence of MYMV was recorded Pant Moong-1 (6.00\%) followed by SML-668 (24.33\%) and highest in Pusa Baisakhi (39.00\%) followed by Type44 (34.11\%) and PS-16 (32.44\%). The severity of disease incidence increases with the increase in the mean number of whitefly population in the mungbean. During Kharif 2014, (Table 3) mean whitefly population per plant on different mungbean varieties varied from 40.67-82.62. Among the five varieties screened against whitefly, none of the variety was found resistant against whitefly. The variety "Pant Moong-1" was found moderately resistant against whitefly with a score of 11-20. The varieties SML-668, PS-16 and Type-44 were found susceptible with a score of 30-50. Out of the five varieties screened against whitefly, one variety namely "Pusa Baisakhi" was found highly susceptible with a score of more than 50. The MYMV incidence ranged from 15.22 to 79.00 per cent. Significantly low incidence of MYMV was recorded Pant Moong-1 (15.22\%) followed by PS-16 (35.00\%) and highest in Pusa Baisakhi (79.00\%) followed by SML668 (41.66\%) and Type-44 (38.67\%). The severity of disease incidence increases with the increase in the mean number of whitefly population in the mungbean. The present study is in agreement with that of Singh and Singh (2014) who screened 30 genotypes of mungbean [Vigna radiata (L.) Wilezek] against white fly (Bemisia tabaci), and reported minimum population of white fly was recorded on genotype TMB-36, followed by RMG-1004 and maximum in BM-2003-2 and HUM-12.

Table.1 Disease severity was recorded at weekly interval using 0-5 scale (Bashir, 2005)

\begin{tabular}{|c|c|c|c|}
\hline Disease Severity & Per cent infection & Infection category & Reaction Group \\
\hline 0 & All plants free of disease symptoms & Highly resistant & HR \\
\hline 1 & $1-10 \%$ Infection & Resistant & RR \\
\hline 2 & $11-20 \%$ infection & Moderately resistant & MR \\
\hline 3 & $21-30 \%$ infection & Moderately susceptible & MS \\
\hline 4 & $30-50 \%$ infection & Susceptible & S \\
\hline 5 & More than $50 \%$ & Highly susceptible & HS \\
\hline
\end{tabular}


Table.2 Screening of commonly grown mungbean varieties against whitefly causing yellow mosaic virus

(MYMV) during, Zaid season 2014

\begin{tabular}{|c|c|c|c|c|c|c|c|c|c|c|}
\hline \multirow[t]{2}{*}{ S.no. } & \multirow[t]{2}{*}{ Varieties } & \multicolumn{3}{|c|}{ Whitefly population/plant } & \multirow{2}{*}{$\begin{array}{l}\text { Mean no. of } \\
\text { white fly } \\
\text { population }\end{array}$} & \multicolumn{3}{|c|}{$\begin{array}{c}\text { Disease severity } \\
(\%)\end{array}$} & \multirow[t]{2}{*}{$\begin{array}{c}\text { Mean disease } \\
\text { severity }(\%)\end{array}$} & \multirow[t]{2}{*}{$\begin{array}{c}\text { Resistance } \\
\text { rating }\end{array}$} \\
\hline & & 25 DAS* & 50 DAS & 75 DAS & & 25 DAS & 50 DAS & 75 DAS & & \\
\hline 1 & SML- 668 & $\begin{array}{c}3.68 \\
(2.15) \\
\end{array}$ & $\begin{array}{c}4.33 \\
(2.29) \\
\end{array}$ & $\begin{array}{c}6.00 \\
(2.64) \\
\end{array}$ & 4.68 & $\begin{array}{l}21.33 \\
(4.72) \\
\end{array}$ & $\begin{array}{l}24.00 \\
(4.99) \\
\end{array}$ & $\begin{array}{c}27.7 \\
(5.35) \\
\end{array}$ & 24.33 & $\begin{array}{l}\text { Moderately } \\
\text { susceptible }\end{array}$ \\
\hline 2 & $\begin{array}{c}\text { Pusa } \\
\text { Baisakhi }\end{array}$ & $\begin{array}{c}6.00 \\
(2.64) \\
\end{array}$ & $\begin{array}{c}7.69 \\
(2.94) \\
\end{array}$ & $\begin{array}{c}9.30 \\
(3.21) \\
\end{array}$ & 7.69 & $\begin{array}{l}35.37 \\
(6.02) \\
\end{array}$ & $\begin{array}{l}38.35 \\
(6.27) \\
\end{array}$ & $\begin{array}{c}43.3 \\
(6.66) \\
\end{array}$ & 39.00 & Susceptible \\
\hline 3 & PS- 16 & $\begin{array}{l}5.00 \\
(2.44) \\
\end{array}$ & $\begin{array}{c}6.33 \\
(2.70) \\
\end{array}$ & $\begin{array}{c}8.70 \\
(3.11) \\
\end{array}$ & 6.67 & $\begin{array}{l}25.33 \\
(5.11) \\
\end{array}$ & $\begin{array}{l}35.00 \\
(6.00)\end{array}$ & $\begin{array}{c}37.0 \\
(6.16) \\
\end{array}$ & 32.44 & Susceptible \\
\hline 4 & $\begin{array}{c}\text { Pant } \\
\text { Moong- 1 }\end{array}$ & $\begin{array}{c}1.67 \\
(1.63) \\
\end{array}$ & $\begin{array}{c}3.00 \\
(1.99) \\
\end{array}$ & $\begin{array}{c}5.00 \\
(2.44) \\
\end{array}$ & 3.22 & $\begin{array}{c}4.36 \\
(2.94) \\
\end{array}$ & $\begin{array}{c}6.00 \\
(2.63) \\
\end{array}$ & $\begin{array}{c}7.7 \\
(2.94) \\
\end{array}$ & 6.00 & Resistant \\
\hline 5 & Type- 44 & $\begin{array}{c}4.33 \\
(2.31)\end{array}$ & $\begin{array}{c}6.00 \\
(2.64)\end{array}$ & $\begin{array}{c}7.30 \\
(2.89)\end{array}$ & 5.89 & $\begin{array}{l}31.34 \\
(5.68)\end{array}$ & $\begin{array}{l}34.33 \\
(5.93)\end{array}$ & $\begin{array}{c}36.7 \\
(6.14)\end{array}$ & 34.11 & Susceptible \\
\hline \multicolumn{2}{|c|}{ CD at $5 \%$} & 0.408 & 0.493 & 0.258 & & 0.720 & 0.537 & 0.343 & & \\
\hline \multicolumn{2}{|c|}{$\operatorname{SEm}( \pm)$} & 0.123 & 0.133 & 0.078 & & 0.217 & 0.162 & 0.104 & & \\
\hline
\end{tabular}

*DAS - Days after sowing

Table.3 Screening of commonly grown mungbean varieties against whitefly causing yellow mosaic virus

(MYMV) during, Kharif season 2014

\begin{tabular}{|c|c|c|c|c|c|c|c|c|c|c|}
\hline \multirow[t]{2}{*}{ S.no. } & \multirow[t]{2}{*}{ Varieties } & \multicolumn{3}{|c|}{ Whitefly population/plant } & \multirow{2}{*}{$\begin{array}{l}\text { Mean no. of } \\
\text { white fly } \\
\text { population }\end{array}$} & \multicolumn{3}{|c|}{$\begin{array}{c}\text { Disease severity } \\
(\%)\end{array}$} & \multirow[t]{2}{*}{$\begin{array}{c}\text { Mean disease } \\
\text { severity }(\%)\end{array}$} & \multirow[t]{2}{*}{$\begin{array}{c}\text { Resistance } \\
\text { rating }\end{array}$} \\
\hline & & 25 DAS* & 50 DAS & 75 DAS & & 25 DAS & 50 DAS & 75 DAS & & \\
\hline 1 & SML- 668 & $\begin{array}{l}58.67 \\
(7.72)\end{array}$ & $\begin{array}{c}4.68 \\
(2.38)\end{array}$ & $\begin{array}{l}45.69 \\
(6.83)\end{array}$ & 48.89 & $\begin{array}{l}35.67 \\
(6.05)\end{array}$ & $\begin{array}{l}42.00 \\
(6.55)\end{array}$ & $\begin{array}{l}47.35 \\
(6.95)\end{array}$ & 41.66 & Susceptible \\
\hline 2 & Pusa Baisakhi & $\begin{array}{l}77.00 \\
(8.83)\end{array}$ & $\begin{array}{l}82.67 \\
(9.14)\end{array}$ & $\begin{array}{l}88.33 \\
(9.45)\end{array}$ & 82.62 & $\begin{array}{l}69.33 \\
(8.38)\end{array}$ & $\begin{array}{l}82.33 \\
(9.12)\end{array}$ & $\begin{array}{l}85.33 \\
(9.29)\end{array}$ & 79.00 & $\begin{array}{c}\text { Highly } \\
\text { Susceptible }\end{array}$ \\
\hline 3 & PS- 16 & $\begin{array}{l}60.33 \\
(7.83) \\
\end{array}$ & $\begin{array}{l}58.69 \\
(7.72)\end{array}$ & $\begin{array}{l}62.33 \\
(7.95)\end{array}$ & 60.44 & $\begin{array}{l}33.00 \\
(5.83)\end{array}$ & $\begin{array}{l}35.00 \\
(6.00)\end{array}$ & $\begin{array}{l}37.00 \\
(6.16)\end{array}$ & 35.00 & Susceptible \\
\hline 4 & $\begin{array}{c}\text { Pant Moong- } \\
1 \\
\end{array}$ & $\begin{array}{l}38.00 \\
(6.24) \\
\end{array}$ & $\begin{array}{l}41.00 \\
(6.47)\end{array}$ & $\begin{array}{l}43.00 \\
(6.63)\end{array}$ & 40.67 & $\begin{array}{l}12.67 \\
(3.69)\end{array}$ & $\begin{array}{l}15.33 \\
(4.04)\end{array}$ & $\begin{array}{l}17.67 \\
(4.32)\end{array}$ & 15.22 & $\begin{array}{c}\text { Moderately } \\
\text { resistant }\end{array}$ \\
\hline 5 & Type- 44 & $\begin{array}{l}73.01 \\
(8.60)\end{array}$ & $\begin{array}{l}75.33 \\
(8.74)\end{array}$ & $\begin{array}{l}77.33 \\
(8.85)\end{array}$ & 75.22 & $\begin{array}{l}34.33 \\
(5.94)\end{array}$ & $\begin{array}{l}37.33 \\
(6.19)\end{array}$ & $\begin{array}{l}44.33 \\
(6.73)\end{array}$ & 38.67 & Susceptible \\
\hline \multicolumn{2}{|c|}{ CD at $5 \%$} & 0.489 & 0.517 & 0.484 & & 0.328 & 0.572 & 0.303 & & \\
\hline \multicolumn{2}{|c|}{$\operatorname{SEm}( \pm)$} & 0.148 & 0.156 & 0.146 & & 0.099 & 0.173 & 0.091 & & \\
\hline
\end{tabular}

*DAS - Days after sowing 
The present study is in line with Iqbal and Iqbal, (2011) who screened one hundred genotypes/lines of mungbean germplasm against mungbean yellow mosaic virus (MYMV) under field conditions.

They evaluated differential response of mungbean accessions to MYMV and none of the genotype/line was reported to be highly resistant to disease. Four genotypes/lines i.e. 014043, 014133, 014249, 014250 were reported as resistant. Eight were moderately resistant and 30 were moderately susceptible whereas remaining 30 accessions were classified as susceptible and 43 as highly susceptible accessions. Similarly, Paul et al., (2013) reported that out of 18 mungbean germplasm, and found one Resistant (R), 9 Moderately Resistant (MR), 7 Moderately Susceptible (MS) and only one accessions was found Susceptible (S). Minimum incidence $4.80 \%$ was recorded from variety ML-818 and found resistant (R) against MYMV. Whereas, variety Pusa-Baishakhi was found most susceptible (S) in this region and showed maximum incidence of $21.03 \%$. Our results are also in agreement with Sana Habib et al., (2007) reported out of 108 test lines, the two test lines NM-38-203-34 and NCM-257-10-36 showed the minimum incidence of 8 per cent, and eight test lines exhibited 17 per cent incidence. The remaining test lines showed the disease incidence ranging from 33-67 per cent.

\section{Acknowledgments}

The authors are thankful to the Head, Division of Entomology, SKUAST-Jammu for providing all necessary facilities for experiments.

\section{References}

Bashir, M. 2005. Studies on viral diseases of major pulse crops and identification of resistant sources. Technical Annual Report (April, 2004 to June, 2005) of ALP Project. Crop Sciences Institute, National Agricultural Research Centre, Islamabad. pp. 169.

Iqbal, U. and Iqbal, M.S. 2011. Screening of mungbean germplasm against mungbean yellow mosaic virus (MYMV) under field conditions. Pakistan J. Phytopath., 23(1): 48-51.

Marimuthu, T., Subramanian, C.L. and Mohan, R. 1981. Assessment of yield losses due to yellow mosaic infection in mungbean. Pulse Crops News, 1: 104.

Paul, P.C., Biswas, P.K., Mandal, D. and Pal, P. 2013. Studies on host resistance of mungbean against mungbean yellow mosaic virus in the agro-ecological condition of lateritic zone of West Bengal. The Bioscan, 8(2): 583-587.

Sana Habib, Nadeem Shad, Arshad Javaid and Umer Iqbal. 2007. Screening of mungbean germplasm for resistance/tolerance against yellow mosaic disease. Myco. Path., 5(2): 89-94.

Sekar, S. and Nalini, R. 2017. Varietal Screening of Mungbean Genotypes against Whitefly (Bemisia tabaci Genn.), Mungbean Yellow Mosaic Virus (MYMV) and Cercospora Leaf Spot. Int. J. Curr. Microbial. App. Sci., 6(3): 12781285.

Singh, S. K. and Singh, P. S. 2014. Screening of mungbean (Vigna radiata) genotypes against major insects Curr. Adv. Agri. Sci., 6(1): 85-87.

\section{How to cite this article:}

Nadeya Khaliq, Virender Koul, Uma Shankar, Suheel Ahmad Ganai, Sonika Sharma and Thanlass Norboo. 2017. Screening of Mungbean (Vigna radiata (L.) Wilczek) Varieties against Whitefly (Bemisia tabaci Genn.) and Mungbean Yellow Mosaic Virus (MYMV). Int.J.Curr.Microbiol.App.Sci. 6(8): 129-132. doi: https://doi.org/10.20546/ijcmas.2017.608.017 